\title{
An Integrative Terror Management Theory Perspective on Media Effects: A Model and 12 Hypotheses for Research
}

\author{
Richard M. Perloff \\ Correspondence; Richard M. Perloff, School of Communication, Cleveland State University, USA
}

Received: March 31, 2016 Accepted: April 19, 2016 Online Published: May 10, 2016

doi:10.11114/smc.v4i1.1600

URL: http://dx.doi.org/10.11114/smc.v4i1.1600

\begin{abstract}
This paper is designed to stimulate theory-driven research on the implications of Terror Management Theory (TMT) for a host of intriguing media phenomena. The paper synthesizes previous research, presents a model of TMT influences, and suggests 12 hypotheses for study in diverse areas, notably, media entertainment, news, advertising, fear appeals, and social media. A terror management perspective, with its emphasis on the novel, counterintuitive ways individuals keep death at bay, can extend knowledge in different areas of the field, illuminate understanding of media influences, and generate a host of studies that chart new pathways for comprehension of contemporary communication.
\end{abstract}

Keywords: terror management theory, mortality salience, mass media influences, news, fear appeals

\section{Introduction}

Terror management theory (TMT), with its existential roots (Greenberg \& Arndt, 2012; Pyszczynski, Greenberg, \& Koole, 2004), has generated intriguing, counterintuitive, and robust findings about the social psychology of death. In light of the communication discipline's time-honored emphasis on meaning-making and construction (e.g., Cronen, Pearce, \& Harris, 1982; Dervin, 1989), the theory's examination of how individuals construct meaning in the wake of ineluctable mortality, and its implications for pervasive use of media, would seem to lend itself naturally to empirical research in communication. Yet there have been only a paucity of studies exploring these issues. To be sure, there have been a variety of interesting communication-focused studies that have examined the interface between aspects of TMT and fear appeals (e.g., Dilliplane, 2010; Moore, Thorson, \& Leshner, 2011), advertising (Dar-Nimrod, 2012), and news (Das, Bushman, Bezemer, Kerkhof, \& Vermeulen, 2009), along with related work that has explores the link between communication and terrorism (Miller \& Landau, 2005, 2008). Yet, given the specialized nature of the research, and the fitful output of communication studies in this area, there has been insufficient appreciation for the singular insights (and multitudinously rich implications) of TMT for understanding a host of communication effects.

The present paper attempts to redress this imbalance, offering an integrative perspective on terror management and communication effects, and pulling together a number of empirical findings that gain resonance when viewed through a more braided theoretical framework. Teasing out specific implications from Terror Management Theory for a host of communication issues, spanning media entertainment, advertising, politics, and health, and stitching together the fabric of relevant communication studies, in concert with terror management postulates, the present paper presents a host of hypotheses about the interface between terror management and communication concerns that are designed to stimulate programmatic research in the field. Emphasizing theory, the paper is intended to perform an intellectual gadfly-like role, offering up a number of hypotheses for study, as well as an integrative model pointing to pathways for scholarship.

\section{Overview of Terror Management Theory}

To understand Terror Management Theory, one must appreciate its existential roots. Emphasizing with Sartre (1956) that humans are "condemned to be free," and existence precedes essence, existentialists examine human life "in its totality," asking "what the basic conditions of human existence are and how man can establish his own meaning out of these conditions"(Barrett, 1959, p. 126; Pyszczynski, Greenberg, \& Koole, 2004; Proulx, 2013; Vail, Juhl, Arndt, Vess, Routledge, \& Rutjens, 2012). Existentialism assumes that death is a central and preeminent absurdity with which humans must grapple and a threat to life's meaning -- yet at the same time, and ironically, a force that can confer meaning. The psychological implications of death form the foundation of Terror Management Theory.

TMT begins with the Darwinian principle that people are biologically predisposed toward self-preservation, yet are cognizant that their hopes will ultimately be dashed by the inevitability of death. And while poets wistfully suggest that 
even "the cows consider oblivion, mulling it over," (Young, 2015, p. 68), it is only humans who can appreciate the finitude of death. This existential awareness, Greenberg and Arndt (2012) observe, "creates an ever-present potential for intense anxiety, or terror, which must be managed continuously" (p. 402).

The wonderful - and adaptive - aspect of human nature is that terror can be kept at bay. How? In a word, culture -- or via the internalization of cultural world-views. TMT holds that cultural worldviews stave off the paralyzing terror of death by offering a rich flowering of beliefs about the social universe, beliefs that give life a transcendent meaning, a larger purpose, and can even bear the sweet fruit of providing symbolic immortality through vicarious participation in a host of culturally-sanctioned projects.

In the original, now time-honored, articulation of the theory, theorists articulated several key propositions, all of which have received substantial support from hundreds of studies conducted over the past three decades (see Greenberg \& Arndt, 2012 for a review). First, if faith in a cultural worldview serves as a buffer against death-related anxiety, then reminding individuals of their mortality should motivate people to strengthen their endorsement of foundational cultural values and derogate those who adopt a different perspective. Unsettled by contemplating their own demise, people should seek solace in reifying the bedrock ideology that offers meaning, security and, more profoundly, a sense of belonging to a culture that will persist long after one's lifetime. In a similar fashion, when cognizant of their own ultimate demise, individuals should feel especially threatened by those who oppose a valued worldview, finding opponents' dissonant perspectives deeply affronting, inasmuch as they sunder the ideology that offers a warm blanket of psychological protection against the paralyzing terror of death.

In addition, to the extent that a social psychological structure affords protection from existential concerns about death, buttressing that structure can relieve death-related anxiety (Goldenberg, Pyszczynski, Greenberg, \& Solomon, 2000). Notably, self-esteem, rooted as it is in culture, allays death-related anxiety by strengthening the sense that one is a valued member of the larger culture - i.e., a person making meaningful contributions, recognized by society, to the perpetuation of a broader cultural worldview. Thus, the theory has hypothesized and found that self-esteem enhancement reduces anxiety engendered by thoughts of death (Solomon, Greenberg \& Pyszczynski, 2004).

A newer-though, by now, somewhat established-theoretical focus departs from the highly symbolic, culturally-embroidered ways that the mind seeks to deny the inevitability of death. Instead, it focuses on the body, "the rub," an Achilles heel "which remains ineluctably finite and so may potentially be viewed by individuals as a reminder of their mortality" (Goldenberg, Kosloff, \& Greenberg, 2006, p. 128). Human efforts to transcend or "fly above" mortality concerns (Cohen, Sullivan, Solomon, Greenberg, \& Ogilvie, 2011) by immersing the self in symbolically rich, cognitively meaningful worldviews are concretely punctured by reminders of the body, with its basic, sometimes gross, bodily functions, and the multitude of corporeal, creaturely components of a body that mere, mortal animals also possess. Research has found that when reminded of death, individuals evinced greater disgust with body products and animals; mortality salience also causes participants to like an essay emphasizing that humans differ from animals significantly more than an essay that focused on human-animal similarities (see Goldenberg \& Roberts, 2004 for a review). Thinking about the brute animalistic attributes of the human body or reminding people they share similarities with animals can increase mortality salience concerns, making it more difficult, in these cases, for people to rely on the lofty, meaning-embroidered modes to ward off awareness of death (Heflick \& Goldenberg, 2014).

Common to all this work is the assumption that existential terror operates at deep levels of human thought, permeating the conscious, but also the unconscious, mind. The two levels at which terror management occur have different psychological - and, as will be seen, communication -- implications (Pyszczynski, Greenberg, \& Solomon, 1999). A conscious reminder of death - experimentally induced with a manipulation of mortality salience -- sets in motion proximal defenses, where the individual, at least in the short-term, takes rational steps to deal with the problem, or, alternatively, denies vulnerability to danger. But the essence of life is that the terror aroused by the reminder of mortality salience returns, though the thoughts, pushed to the back of one's mind, are no longer conscious, yet are accessible. It is under these conditions that people must resort to indirect, symbolic, distal defenses, whereby they invoke cultural worldviews, meaning-centered values and self-esteem to maintain the cognitive equilibrium that enables them to live life without the paralyzing anxiety that reminders of death inevitably engender (Pyszczynski, Greenberg, Solomon, \& Maxfield, 2006).

In the many experimental tests of the hypotheses, TMT hypotheses primarily receive support when a delay ensues between the manipulation of mortality salience and measurement of the dependent variable. Immediately after the manipulation, individuals rationally employ proximal defenses to eliminate anxiety about death. But after a delay, when participants relax their suppression of death-related cognitions, thoughts of death return, though they are outside conscious awareness, yet accessible. It is under these conditions that individuals necessarily resort to the host of distal terror management strategies that push death thoughts back to pre-induction baseline levels and keep terror at bay 
(Pyszczynski, Greenberg, \& Solomon, 1999; Pyszczynski, Greenberg, Solomon, \& Maxfield, 2006).

From a communication perspective, proximal defenses are less interesting than distal, symbolic mechanisms. When individuals are conscious of mortality, they consciously take steps to deny or ward off danger in ways that are congenial with our present theories. However, it is when thoughts of death are no longer conscious, but highly accessible - i.e., the day-to-day fate of humankind, confronted with existential angst, or, more concretely, when situationally-primed death thoughts recede from conscious awareness--that people invoke distal TMT defenses, such as bolstering cultural worldviews, striving for meaning, and enhancing self-esteem.

Accordingly, the hypotheses presented in the next sections of the paper presume that distal defenses are operative and death thoughts occur outside conscious awareness. Hypotheses are framed in terms of mortality salience, given the clarity of the term, but operationally, it is presumed that there is a delay between measurement or manipulation of mortality awareness and the dependent variables. Figure 1 offers a visual summary, a schematic diagram, of the thrust of the hypotheses to come. Note that, as TMT emphasizes, when mortality salience triggers conscious, proximal, rational defenses, implications for media uses and effects do not depart from those emphasized by present theories. It is only when nonconscious thoughts of death are accessible and distal defenses operate that TMT carries intriguing, newer implications for communication. To be sure, a variety of alternative explanations of mortality salience findings have been put forth, not all persuasive in the view of TMT researchers (Pyszczynski, Greenberg, Solomon, \& Maxfield, 2006). Nonetheless, sorting out mechanisms remains an engaging area for future research, but extends beyond the purview of the present paper. 
TMT Inputs

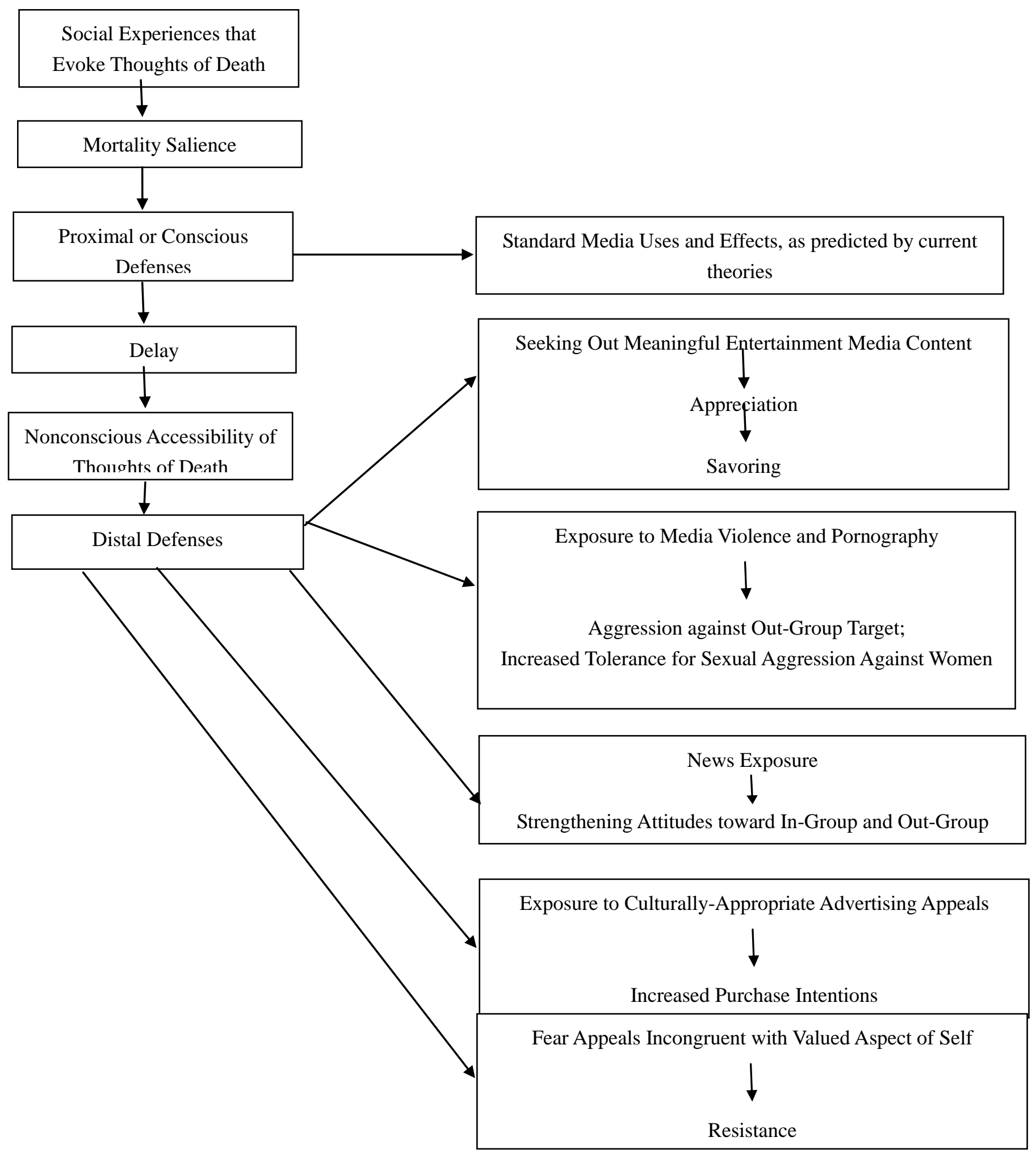

Figure 1. Terror Management Theory Applications to Media Uses and Effects 


\section{Media and Terror Management}

\subsection{Entertainment Media Appreciation}

Increasingly, communication scholars have recognized that there is more to entertainment than fun, joy, or enjoyment. Deeper meanings are at stake. Over the past decade, media psychology scholars have come to appreciate that the time-honored concept of enjoyment, while still relevant to the study of media entertainment, neglects the deeper -frequently sadder and even tragic - media fare that engages and engrosses audience members (Oliver \& Woolley, 2011).

Contrary to classic mood management theory (Zillmann, 1988), which emphasizes that media users try to maintain positive mood-states, newer approaches emphasize that individuals have a variety of reasons to seek out tragic, sad mood-inducing media fare, and sometimes do exactly this (Oliver, 2008; Vorderer, Klimmt, \& Ritterfeld, 2004).Taking a page from Aristotle's philosophical distinctions in Nicomachean Ethics, where he differentiates between mere hedonic happiness and the "truer" happiness that comes from the pursuit of virtue, researchers have begun to focus on the latter, called eudaimonia, or happiness derived from a more meaning-tinged focus on personal expressiveness and self-fulfillment (Oliver \& Woolley, 2011; Waterman, 1993).

Building on this concept, as well as other work emphasizing that the appeal of story-focused media entertainment is driven by higher-level "meta-emotions" involving self-reflection on unpleasant feelings (Vorderer, Klimmt, \& Ritterfeld, 2004; see also Slater, Johnson, Cohen, Comello, \& Ewoldsen, 2014), Oliver and Bartsch (2010) embarked on research exploring deeper entertainment gratifications. Their research, as well as Bartsch, Kalch, and Oliver (2014), suggests that in addition to the more familiar hedonistic gratifications associated with enjoyment, people also seek out gratifications associated with meaning. Appreciation -- not the opposite of enjoyment, but a complementary entertainment experience - is conceptualized as an audience response to entertainment associated with meaning-centered gratifications and eudaimonic concerns involving positive and negative affective reactions (Oliver \& Woolley, 2011).

As the previous discussion emphasized, empirical studies have swiftly begun to hone in on the psychologically complex (but experientially stimulating) phenomenon of meaningfulness as a media entertainment experience. This naturally raises the next issue in the progression of scientific research - when (e.g., Zanna \& Fazio, 1982), or the conditions under which particular effects occur. This requires a specification of factors that motivate seeking out meaningful entertainment fare and articulating factors that moderate and mediate media appreciation. Enter TMT, a theory exquisitely focused on the existential search for meaning.

TMT suggests that the need to manage existential terror extends to the profound and the poignant. It motivates individuals to seek out and derive particular rewards from moving or meaningful media content. Meaningful content is defined as content that leads individuals to contemplate human virtues, such as "justice, courage, gentleness, generosity, truthfulness, knowledge, wisdom, and intuition" (Tamborini, 2011, pp. 43-44). From a theory-building perspective, this suggests that mortality salience can influence uses and gratifications of media entertainment. When thoughts of death are nonconscious, but accessible, and distal defenses are invoked, individuals will be motivated to seek ways to affirm the underlying meaning of human life, in this way palliating the anxiety produced by the awareness of death and imbuing everyday encounters with deeper, even transcendental significance. Research indicates that individuals display interest in viewing eudaimonic media content that satisfies affective needs (Oliver, 2008), preferring storylines that bear on their experiences, even if the plots are not hedonically pleasurable (Nabi, Finnerty, Domschke, \& Hull, 2006).The foregoing discussion suggests the following hypothesis:

H1: When mortality is salient, individuals will prefer content that is sad, tragic, and involves human connectedness over more hedonically pleasant content, such as comedy and action.

Not only should individuals be drawn to this type of entertainment under these circumstances, but they should attend more closely to it, finding solace in the ways the film or art form meaningfully depicts a larger symbolic universe which offers transcendent purpose and restores psychological equilibrium. Indeed, there is evidence that when mortality is salient, individuals are particularly likely to appreciate a meaningful film (Rieger, Frischlich, Högden, Kauf, Schramm, \& Tappe, 2015), notably if they highly evaluated search for meaning in life (Hofer, 2013), and to respond emotionally to a tragic literary excerpt (Goldenberg, Pyszczynski, Johnson, Greenberg, \& Solomon, 1999). Thus, mortality salience is likely to moderate the impact of meaningful media fare on appreciation. This raises the question of the processes by which this occurs.

Research offers specific clues. Motivated to allay mortality concerns and hoping to do so through media appreciation, individuals reminded of death should process meaningful media content deliberatively and even contemplatively (Lewis, Tamborini, \& Weber, 2014; Knobloch-Westerwick, Gong, Hagner, \& Kerbeykian, 2013). Striving to find meaning in the wake of a reminder of inevitable death, they should immerse themselves in meaningful media content that spans 
literature, movies, and interactive art forms, becoming psychologically transported by the content, mentally involved and cognitively catapulted to the world of the author's imagination (Green, Brock, \& Kaufman, 2004). They should also report feeling moved by what they read or see, suggested by Bartsch et al. (2014), who discovered that the effects of a moving, death-related film on film evaluations were mediated by an affective state, intriguingly called "feeling moved" (which consisted of negative valence, mixed affect, and moderate arousal), and reflective thoughts, such as reporting that the movie induced thinking about oneself. This suggests the following hypothesis:

$\mathrm{H} 2$ : The effects of mortality salience on appreciation of meaningful media content will be mediated by transportation, feeling moved, and reflective thoughts.

Mortality salience should extend beyond appreciation. Theoretically, the appreciation conferred by a movie, book, or tragic, but thought-provoking, art form should be rewarding and gratifying, in that it helps buffer death-related anxiety. The pleasant blanket of meaning produced by exposure to meaningful media entertainment should motivate individuals to savor it all the more.

Savoring is precisely the experience that should follow entertainment, and there is extensive research explicating and empirically examining the concept. Bryant and Veroff (2007) describe savoring as a positive, affirmative counterpart of psychological coping, specifically defining it as the processes underlying people's "capacities to attend to, appreciate, and enhance the positive experiences in their lives" (p. 2). Although they define savoring in terms of the constellation of an individual's sensations, perceptions, thoughts, and emotions that are experienced "when mindfully attending to and appreciating a positive stimulus" (p. 13), they acknowledge that people can savor aesthetic responses to a tragic or mournful artistic work, and, more generally, that savoring can also come into play when people derive meaning from poignant, unpleasant life situations.

Bryant (2003) and Bryant and Veroff (2007) have developed psychometrically-validated inventories to measure savoring, such as a Savoring Beliefs Inventory and a Ways of Savoring Checklist. Given the impact of mortality salience on motivation to extract meaning, individuals reminded of death should be impelled to savor and enhance their appreciation of meaningful media content. This suggests the following prediction:

H3: When mortality is salient, appreciation that results from exposure to meaningful media content will lead to savoring of the aesthetic experience.

The hypotheses have intriguing theoretical implications. One might suggest that in the wake of events that activate nonconscious thoughts of death, people will derive particular satisfaction from entertainment programs that tap more meaningful aspects of life. Although the hedonically-centered mood management approach might simplistically suggest that comedies are the best medicine in such circumstances, the present approach emphasizes precisely the opposite prescription: mediated messages that touch on death and offer metaphysically nuanced eudaimonic content should offer a deeper solace. For the mortality salient, meaning is the most medicinal message.

\subsection{Media Violence and Pornography}

Violence. There is voluminous evidence that media violence exerts a causal impact on aggressive behavior (Swing \& Anderson, 2010). Although one might think after six decades of research, there is little left to document, researchers continue to demonstrate how previously-unexplored influences, such as exposure to distressing economic news, instigate aggression (Barlett \& Anderson, 2014). The General Aggression Model stipulates - with supportive evidence that person factors and situational variables affect internal states that in turn influence subsequent aggressive behavior (DeWall \& Anderson, 2011). It is a complex process, but given that brief reminders of economic stress can activate aggression, it is reasonable to believe, in light of TMT findings, that brief reminders of mortality can moderate media violence effects, and instigate aggression, albeit of a particular culturally-resonant kind. In this way, TMT can specify a new condition under which violence and, as we will see, pornography exerts anti-social influences.

Research shows that mortality salience enhances agreement with individuals who vindicate our cultural worldviews and increases disagreement with others who are presumed to be hostile to our viewpoints, intriguingly demonstrated in a study by Greenberg, Pyszczynski, Solomon, Rosenblatt, Veeder, Kirkland, \& Lyon, 1990) that found when reminded of death, Christian participants reported greater liking for a Christian target and more negative reactions to a Jew. What's more, following mortality salience, participants were willing to aggress against individuals with opposing political views, even to the point of giving them hot sauce (McGregor, Lieberman, Greenberg, Solomon, Arndt, Simon, \& Pyszczynski, 1998). With morality salient and individuals motivated to derogate out-group members, exposure to media violence should be especially likely to prime aggressive thoughts and actions. This suggests the following hypothesis:

H4: When mortality is salient, individuals exposed to media violence will be more likely to harbor aggressive thoughts and display short-term aggressive behavior against an out-group target who expresses hostility toward the participant's cultural worldview. 
Pornography. What does mortality salience have to do with pornographic portrayals, one may ask? It turns out that the answer is exquisitely complex and points to an interesting hypothesis. Goldenberg's theoretical corollary described earlier emphasizes how reminders of the brute physicality of the human body can undermine the effectiveness of death-denying coping mechanisms focusing on symbolic immortality and transcendent cultural meaning. When you are reminded of your animal-like, creaturely nature, and a physical body that inevitably will disintegrate, it is hard to sustain faith in grand, meaning-imbuing projects that will endure over time immemorial. Thus, mortality salience reduces men's attraction to a sexually attractive woman, presumably because she carries the reminder that body trumps mind, and physicality (however alluring) will spell the end of symbolic efforts to deny death (Landau, Goldenberg, Greenberg, Gillath, Solomon, Cox, Martens, \& Pyszczynski, 2006; Goldenberg, 2013). But here is where the dynamic takes an intriguing turn.

Men reminded of death, who are struggling to transcend their bodily, pleasure-seeking needs, are being "pulled back" by women's physical appeal. As Landau et al. (2006) explained, "if women's sexual allure serves as an unwanted reminder for men of their own corporeality and thereby undermines terror management, then reminders of one's susceptibility to women's seductive influence should, under conditions of MS, incite negative feelings toward women" (p. 139). According to this view, men, frustrated by the ways that women's sexual appeal threatens their ability to manage terror, lash out against the source of frustration - i.e., women. Consistent with this notion, men reminded of their sexual lust after mortality salience showed greater tolerance of aggression against women (Landau et al., 2006). By essentially objectifying women, transforming them into objects of aggression to justify terror management needs, men further depersonalize and dehumanize women. This can have disturbing consequences.

Objectified women are perceived to have less mind and moral status than non-objectified women (Loughnan, Haslam, Murnane, Vaes, Reynolds, \& Suitner, 2010). Men who associated women with primitive, animal attributes were more likely than other men to report that they would be inclined to rape women if they would not get caught, and to display negative attitudes toward rape victims (Rudman \& Mescher, 2012). To be sure, these are self-report measures, but they are intriguingly suggestive, for pornography exposes men to primitive depictions of women and even bestiality, which, under conditions of mortality salience, can undermine psychological defenses. We know from Zillmann and Bryant's (1982) classic study that massive exposure to pornography leads to calloused attitudes toward women, including devaluing of Women's Liberation and recommendation of more lenient punishment of rape victims. Pornography depicts a devalued, highly sexualized portrait of women devoid of the romantic aspects that can alleviate terror management needs by placing women on a symbolic pedestal, offering meaning and grandiosity. Instead, pornography contains the brute, frequently alluring, physical depictions of women that should unnerve men's attempts, in the wake of mortality salience, to transcend their corporeality, subverting terror management and leading to the negative feelings reported above. This suggests the following hypothesis:

H5: When mortality is salient, men exposed to pornographic depictions of women should display more negative attitudes toward women and show more tolerance for sexual aggression against women.

Theoretically-driven research, such as that proposed above, can advance knowledge of media violence effects. We know that young people are more susceptible to media violence effects when they are low in psychological well-being (Comstock, 2004). And, of course, the flip side of the TMT self-esteem buffer hypothesis is that mortality salience effects are greater on those with low self-esteem (Kashima, Halloran, Yuki, \& Kashima, 2004). When individuals are low in self-esteem, either situationally or chronically, they are less capable of believing that they are actively contributing to a meaningful culture, which makes them more susceptible to existential terror. If we couple these two findings -- media violence effects are more likely when individuals are low in psychological well-being, and low self-esteem exacerbates mortality salience effects - we have the beginnings of a perfect storm. When the social environment activates thoughts of death or peels a layer through proximal defenses, the low self-esteem male audience members who are consuming media violence or violent pornography should be particularly likely to display anti-social attitudes and behaviors.

\section{Terror Management and News}

The news media convey cultural narratives, diffusing value-laden stories that influence attitudes and beliefs (Gerbner, Gross, Morgan, \& Signorielli, 1986). Beginning in the nineteenth century, as new press technologies and media economics encouraged distribution of images of disaster and metropolitan murders, the news media began to sensationalize mayhem and violent deaths (Goldberg, 1998). The iconography of death now dominates news, with depictions of death by fire, hurricanes, car crashes, Ebola, wars, and terrorist attacks ubiquitous. News, with its multiple, vivid, and salient depictions of death, can prime mortality in ways other media genres cannot. Viewers can discount entertainment portrayals as fiction. However, even if they are psychologically transported to different mental arenas, depictions of death in news have a verisimilitude that makes the depictions harder to shake off. To the extent that deaths 
depicted on news result from violence, and many do, their perceived reality is likely to strengthen news media effects (Harris \& Sanborn, 2014). News of death also occurs in a cultural context; thus, mortality that has been primed threatens the valued cultural worldview that underpins defenses against existential angst (see Das et al., 2009; Landau, Solomon, Greenberg, Cohen, Pyszczynski, Arndt, Miller, Ogilvie, \& Cook, 2004). News should prime mortality and once primed, TMT suggests that mortality salience causes individuals to seek cognitive equanimity by bolstering a cultural worldview that aggrandizes the in-group and disparages the out-group.

There is intriguing variability in the nature of deaths vicariously experienced through exposure to news. Such events include terrorism or military attacks, but also political assassinations, such as JFK's, that roil a nation; acts wrought by Nature, such as Hurricane Katrina, which personally touched many vulnerable Black residents of New Orleans; the deaths of Michael Brown in Ferguson, Missouri and Freddie Gray in Baltimore, which galvanized African American protesters in cities that faced years of police bias; and murders of police officers, such as the two policemen gunned down in New York City in 2014 that led many New York cops to rally around fellow in-group policemen, while turning their backs on the (out-group) city's mayor at a hospital news conference (Flegenheimer, 2014). In these cases, perceived similarity between news viewers and the dead underlie psychological closeness, suggesting that news about horrific deaths will be particularly likely to intensify attitudes and bolster cultural worldviews when perceived similarity between the self and victim makes personal mortality salient, setting in motion the range of TMT effects. This suggests the following prediction:

H6: News about deaths will lead to more positive attitudes toward the in-group and more prejudiced attitudes toward the out-group, only if the deaths are perceived to be physically or psychologically close to news viewers.

This also suggests a subtle effect of news. News of death can activate group identifications, accessing not just personal mortality, but a collective morality, or what Kashima et al. (2004) describe as "the death of a whole in-group." This awareness, they note, "may be particularly disturbing for someone whose collective self (based on group or social category memberships) is especially important" (p. 386). News of assassinations, terrorist attacks on the home soil, and violence seemingly directed at particular groups, such as minorities, religious adherents, or law enforcement, can arouse group identities, activate in-group/out-group perceptions, and access a raw sense of collective mortality. For example, in New York City, immense news coverage of the shooting of the two policemen in December, 2014 may have awakened in NYPD police officers a collective mortality, causing them to want to strengthen the police in-group at the expense of the out-group. Thus, they turned their backs visibly and rudely to the city's mayor, accentuating the in-group and admonishing the liberal mayor, a representative of the out-group. This allowed the city's police officers to keep terror at bay by placing their cultural worldview front and center. This suggests an additional, related hypothesis:

H7: When news prominently covers deaths of in-group members, it will arouse collective mortality concerns. These in turn should strengthen positive attitudes toward the in-group and negative attitudes toward the out-group among in-group members.

TMT suggests one other implication of news, a more political impact. Given that terror can be managed by bolstering cultural worldviews, it stands to reason that when mortality is salient, individuals will be drawn to information that strengthens their political attitudes. Selectively seeking out messages that reinforce one's view of the world (e.g., Stroud, 2011) provides cognitive equanimity, offering the social consensus which reassures the individual that the ultimately-tenuous foundation on which political reality is based is real, meaningful, and true. Such mental repose is particularly gratifying in the wake of reminders of death. This suggests the following hypothesis:

H8: When mortality is salient, individuals will seek out news stories that are congruent with their political worldview.

In sum, the foregoing discussion suggests that when news prominently covers deaths that are perceived to be psychologically close to individuals or touch on in-group identifications, people are apt to close ranks, strengthening in-group attitudes, intensifying antipathy toward the out-group, and selectively tuning into supportive information, all of which undermine efforts to bolster tolerance.

\section{TMT and Persuasive Communication}

\subsection{Advertising}

In the United States, where advertising is showcased on billboards, ballparks, subway turnstiles, and cell phones, and the phrase "shop til you drop" has become part of the cultural lexicon, people seem to have an uncontrollable "urge to splurge" (Arndt, Solomon, Kasser, \& Sheldon, 2004). Consumer values are an integral part of the materialist cultural worldview that help people symbolically cope with existential terror, when nonconscious thoughts of death become cognitively accessible. Guided by this approach, researchers have tested TMT hypotheses in the consumer domain, arguing that "the sheer act of buying may suppress thoughts of death, because the pursuit of wealth and culturally desired commodities may reinforce consumers' materialist worldview" (Das, Duiven, Arendsen, \& Vermeulen, 2014, p. 
834). In line with this notion, researchers have found that advertisements containing a mortality reminder increased product purchase intentions (Das et al., 2014; see also Dar-Nimrod, 2012).

Yet advertising effects can be importantly shaped by broader cultural values. Advertisements in individualistic cultures like the U.S. tend to employ individual-focused appeals, like self-reliance, independence, and personal success, while in more collectivististic countries like Korea, ads emphasize more group-focused appeals like family well-being, in-group benefits, and harmony (Han \& Shavitt, 1994; Cho, Kwon, Gentry, Jun, \& Kropp, 1999). Research indicates that culturally-appropriate advertising appeals are more effective than culturally-inappropriate appeals, with U.S. participants more influenced by ads that emphasize individual benefits and their Korean counterparts more affected by ads promising collectivistic rewards (Han \& Shavitt, 1994). As one might expect, the relationship between culture and advertising is multifaceted, with advertising appeals varying also as a function of the vertical, or hierarchy, and horizontal, or equality, orientation of the culture (Shavitt, Johnson, \& Zhang, 2011). This suggests the following prediction:

H9: Under conditions of mortality salience, culturally-appropriate advertising appeals should be especially likely to increase behavioral intentions to purchase the advertised product.

\subsection{Fear Appeals and Health}

This brings us to health, an important arena in psychology and communication, one rife with terror management implications.

The time-honored study of fear appeals has been influentially guided by Witte's (1992) venerable Extended Parallel Process Model (EPPM), which emphasizes the role of interactions of threat and efficacy in triggering danger control (the healthful process) and fear control (the more defensive, less adaptive process). Although there has been general (but not universal) support for the EPPM, the model, and fear appeals research more generally, are hampered by a lack of knowledge of moderator factors that can illuminate conditions under which EPPM-guided fear appeals increase and inhibit message compliance (Mongeau, 2013). A terror management approach can offer insights on potential moderating conditions. By adapting Goldenberg and Arndt's (2008) terror management health framework to health communication, we can put forth a moderating factor, specifying a condition under which traditional fear appeals are unlikely to change attitudes.

Goldenberg and Arndt (2008) noted that when death-related thoughts are conscious -- made salient, for example, by a fear appeal emphasizing death as a consequence of unhealthy behavior -- individuals invoke proximal defenses, in line with what would be expected from previous health communication research, notably the EPPM. They can act defensively, in line with fear control, or alternatively, at least for a time, undertake preventive actions, in concert with danger control.

The more interesting prediction emerges when individuals' death thoughts lie outside focal awareness, but are still accessible. In these cases, Goldenberg and Arndt suggest that health decisions will be influenced not by the actual relevance of behavior to health, but instead, by its relevance to preserving meaning and upholding the self in the larger cultural system. This generates the counterintuitive but theoretically interesting prediction that when mortality concerns are out of focal awareness, but accessible, individuals will take steps to eliminate the disturbing cognitions by reaffirming meaningful or self esteem-enhancing behaviors, even if they are disadvantageous to one's physical health. Under these conditions, health-oriented messages that focus on standard EPPM criteria, like threat and efficacy, and invoke processes, such as danger control, will be so much beside the point, as they will hit the surface facets of the receiver's mind, while never reaching the deeper layers at work.

Confronted, albeit non consciously, with concerns about death that might impinge on a valued aspect of the self, individuals look to symbolic sources to manage existential terror, finding meaning and self-enhancement by ironically reifying the very behavior that could produce the outcome they dread to contemplate. For example, a mortality salience induction led young men who perceived driving as relevant to their self-esteem to drive recklessly, as measured by self-report and a driving simulator (Taubman Ben-Ari, Florian, \& Mikulincer, 1999). When a delay followed mortality salience and distal defenses were invoked, young women for whom tanned skin was part of their self-esteem displayed less intention to buy sun protection products, even though these products can forestall health risks (Routledge, Arndt, \& Goldenberg, 2004). Intriguingly, Shehryar and Hunt (2005) reported that individuals who were strongly committed to drinking alcohol were more likely to reject a "do not drink and drive" message when death, rather than arrest or serious injury, was the consequence of drinking when driving. By integrating these findings and applying them to the fear appeals area, one can see how mortality salience moderates fear appeal effects, as the following hypothesis suggests:

H10: In the wake of mortality salience, a health-oriented fear appeal advancing a recommendation that is incongruent with a valued aspect of an individual's self-concept will lead to active resistance of the message. 
Notice that this hypothesis, in line with TMT health-focused theory and research (e.g., Goldenberg \& Arndt, 2008), stipulates that mortality salience works in concert with the self-concept to help moderate message effects. Health message threats are distinctive in that they bear directly on core aspects of the self, posing deep-seated threats to individuals with particular standards of value. Theoretically, this suggests that the use of death as a severity manipulation may exert precisely the opposite effect than desired on those for whom the unhealthy behavior is linked with a core aspect of the self and is, therefore, psychologically functional.

Is there any hope, under these conditions, of changing attitudes that are disadvantageous to physical health? TMT argues that the communicative medicine must be meaning-focused and the salve must center on the self. Messages should suggest ways that individuals can find meaning and personal significance in adopting healthful responses. In a word, messages must target the fundamental function the attitude serves, matching the message appeal to the underlying function (Carpenter, Boster, \& Andrews, 2013; for supportive evidence see Arndt, Cox, Goldenberg, Vess, Routledge, Cooper, \& Cohen, 2009; Arndt, Schimel, \& Goldenberg, 2003; and Cox, Cooper, Vess, Arndt, Goldenberg, \& Routledge, 2009). Thus, from a communication perspective, fear appeals directed at individuals whose self-concepts are wrapped up in an unhealthy behavior should not strictly focus on surface-level appeals to health. Instead, they should directly target the root of the problem by developing persuasive appeals that demonstrate how the recommendation can help individuals gain meaning and rewards that are of core importance to the self.

\section{Social Media Effects}

TMT also has implications for social media, in this way extending research on the more traditional mass media and lifting terror management into new interactive domains. Research indicates that morality salience increases the desire for fame, having a star in the galaxy bearing one's name, and liking abstract art that is attributed to a celebrity (Greenberg, Kosloff, Solomon, Cohen, \& Landau, 2010). By identifying with, and basking in the glory, of a celebrity, one vicariously links up with a transcendent cultural force, an icon, a media (if not Milky Way) star, and this can symbolically, if temporally, offer solace against existential angst. This suggests the following theoretical extension to the age of social media:

H11: When mortality is salient, individuals will be especially likely to tweet celebrities, post YouTube videos about famous people, and link up with celebrities on online fan sites.

If reminders of personal mortality cause people to seek out fame, then shouldn't they similarly seize the multiple opportunities afforded by contemporary social media to gain their transcendent moments in the selfie sun? Shouldn't the realization that everything is permanent online provide the symbolic immortality people crave in the wake of the anguishing awareness caused by cognizance of death? This suggests the following prediction:

H12: Mortality salience will increase the likelihood that individuals will post and tweet about themselves, and tag videos in which they appear.

\section{Conclusion}

In sum, TMT has exciting implications for the communication field. It can generate new theoretical directions in communication research, transforming death from an issue to be eschewed, because it is too doleful or difficult to study, into one that can illuminate and deepen knowledge of communication, in this way bringing death to life for a new generation of communication scholars.

\section{References}

Arndt, J., Cox, C. R., Goldenberg, J. L., Vess, M., Routledge, C., Cooper, D. P., \& Cohen, F. (2009). Blowing in the (social) wind: Implications of extrinsic esteem contingencies for terror management and health. Journal of Personality and Social Psychology, 96, 1191-1205. http://dx.doi.org/10.1037/a0015182

Arndt, J., Schimel, J., \& Goldenberg, J. L. (2003). Death can be good for your health: Fitness intentions as a proximal and distal defense against mortality salience. Journal of Applied Social Psychology, 33, 1726-1746. http://dx.doi.org/10.1111/j.1559-1816.2003.tb01972.x

Arndt, J., Solomon, S., Kasser, T., \& Sheldon, K. M. (2004). The urge to splurge: A terror management account of materialism and consumer behavior. Journal of Consumer Psychology, 14, 198-212.

Barlett, C. P., \& Anderson, C. A. (2014). Bad news, bad times, and violence: The link between economic distress and aggression. Psychology of Violence, 4, 309-321. http://dx.doi.org/10.1037/a0034479

Barrett, W. (1959).What is existentialism? Saturday Evening Post, 45(126), 129-130.

Bartsch, A., Kalch, A., \& Oliver, M. B. (2014). Moved to think: The role of emotional media experiences in stimulating reflective thoughts. Journal of Media Psychology, 26, 125-140. http://dx.doi.org/10.1027/1864-1105/a000118 
Bryant, F. B. (2003). Savoring Beliefs Inventory (SBI): A scale for measuring beliefs about savouring. Journal of Mental Health, 12, 175-196. http://dx.doi.org/10.1080/0963823031000103489

Bryant, F. B., \& Veroff, J. (2007). Savoring: A new model of positive experience. Mahwah, NJ: Lawrence Erlbaum Associates.

Carpenter, C., Boster, F. J., \& Andrews, K. R. (2013). Functional attitude theory. In J.P. Dillard \& L. Shen (Eds.), The Sage handbook of persuasion: Developments in theory and practice ( $2^{\text {nd }}$ ed., pp. 104-119). Thousand Oaks, CA: Sage.

Cho, B., Kwon, U., Gentry, J. W., Jun, S., \& Kropp, F. (1999). Cultural values reflected in theme and execution: A comparative study of U.S. and Korean television commercials. Journal of Advertising, 28(4), 59-73. http://dx.doi.org/10.1080/00913367.1999.10673596

Cohen, F., Sullivan, D., Solomon, S., Greenberg, J., \& Ogilvie, D. M. (2011). Finding everland: Flight fantasies and the desire to transcend mortality. Journal of Experimental Social Psychology, 47, 88-102. http://dx.doi.org/10.1016/j.jesp.2010.08.013

Comstock, G. (2004). Paths from television violence to aggression: Reinterpreting the evidence. In L.J. Shrum (Eds.). The psychology of entertainment media: Blurring the lines between entertainment and persuasion (pp. 193-211). Mahwah, NJ: Erlbaum Associates.

Cox, C. R., Cooper, D. P., Vess, M., Arndt, J., Goldenberg, J. L., \& Routledge, C. (2009). Bronze is beautiful but pale can be pretty: The effects of appearance standards and mortality salience on sun-tanning outcomes. Health Psychology, 28, 746-752.

Cronen, V. E., Pearce, W. B., \& Harris, L. M. (1982). The coordinated management of meaning: A theory of communication. In F.E.X. Dance (Ed.), Human communication theory: Comparative essays (pp. 61-89). New York: Harper \& Row.

Dar-Nimrod, I. (2012). Viewing death on television increases the appeal of advertised products. Journal of Social Psychology, 152, 199-211. http://dx.doi.org/10.1080/00224545.2011.588273

Das, E., Bushman, B. J., Bezemer, M. D., Kerkhof, P., \& Vermeulen, I. E. (2009). How terrorism news reports increase prejudice against outgoups: A terror management account. Journal of Experimental Social Psychology, 45, 453-459. http://dx.doi.org/10.1016/j.jesp.2008.12.001

Das, E., Duiven, R., Arendsen, J., \& Vermeulen, I. (2014). Exploring killer ads: A terror management account of death in advertisements. Psychology and Marketing, 31, 828-842. http://dx.doi.org/10.1002/mar.20737

Dervin, B. (1989).Users as research inventions: How research categories perpetuate inequities. Journal of Communication, 39, 216-232. http://dx.doi.org/10.1111/j.1460-2466.1989.tb01053.x

DeWall, C. N., \& Anderson, C. A. (2011). The General Aggression Model. In P. Shaver \& M. Mikulincer (Eds.), Human aggression and violence: Causes, manifestations, and consequences (pp. 15-33). Washington, DC: American Psychological Association. http://dx.doi.org/10.1037/12346-001

Dilliplane, S. (2010). Raising the specter of death: What terror management theory brings to the study of fear appeals. In C.T. Salmon (Ed.), Communication Yearbook 34 (pp. 93-132). New York: Routledge.

Flegenheimer, M. (2014). For de Blasio, attack comes amid tension over police. The New York Times. Retrieved from http://www.nytimes.com/2014/12/21/nyregion/worst-case-scenario-c...

Gerbner, G., Gross, L., Morgan, M., \& Signorielli, N. (1986). Living with television: The dynamics of the cultivation process. In J. Bryant \& D. Zillmann (Eds.), Perspectives on media effects (pp. 17-40). Hillsdale, NJ: Erlbaum.

Goldberg, V. (1998). Death takes a holiday, sort of. In J. Goldstein (Ed.), Why we watch: The attractions of violent entertainment (pp. 27-52). New York: Oxford University Press.

Goldenberg, J. L. (2013). Immortal objects: The objectification of women as terror management. In S.J. Gervais (Ed.), Objectification and (de)humanization: 60th Nebraska Symposium on Motivation (pp. 73-95). New York: Springer Science+Business Media. http://dx.doi.org/10.1007/978-1-4614-6959-9_4

Goldenberg, J. L., \& Arndt, J. (2008). The implications of death for health: A terror management health model for behavioral health promotion. Psychological Review, 115, 1032-1053. http://dx.doi.org/10.1037/a0013326

Goldenberg, J. L., \& Roberts, T. A. (2004). The beast within the beauty: An existential perspective on the objectification and condemnation of women. In J. Greenberg, S.L. Koole, \& T. Pyszczynski (Eds.), Handbook of experimental existential psychology (pp. 71-85). New York: Guilford Press. 
Goldenberg, J. L., Kosloff, S., \& Greenberg, J. (2006). Existential underpinnings of approach and avoidance of the physical body. Motivation and Emotion, 30, 127-134. http://dx.doi.org/10.1007/s11031-006-9023-z

Goldenberg, J. L., Pyszczynski, T., Greenberg, J., \& Solomon, S. (2000). Fleeing the body: A terror management perspective on the problem of human corporeality. Personality and Social Psychological Review, 4, 200-218.

Goldenberg, J. L., Pyszczynski, T., Johnson, K. D., Greenberg, J., \& Solomon, S. (1999). The appeal of tragedy: A terror management perspective. Media Psychology, 1, 313-329. http://dx.doi.org/10.1207/s1532785xmep0104_2

Green, M. C., Brock, T. C., \& Kaufman, G. F. (2004). Understanding media enjoyment: The role of transportation into narrative worlds. Communication Theory, 14, 311-327. http://dx.doi.org/10.1111/j.1468-2885.2004.tb00317.x

Greenberg, J., \& Arndt, J. (2012). Terror management theory. In P.A.M. Van Lange, A.W. Kruglanski, \& E.T. Higgins (Eds.), Handbook of theories of social psychology (Vol. 1, pp. 398-415). Thousand Oaks, CA: Sage. http://dx.doi.org/10.4135/9781446249215.n20

Greenberg, J., Kosloff, S., Solomon, S., Cohen, F. \& Landau, M. (2010). Toward understanding the fame game: The effect of mortality salience on the appeal of fame. Self and Identity, 9, 1-18. http://dx.doi.org/10.1080/15298860802391546

Greenberg, J., Pyszczynski, T., Solomon, S., Rosenblatt, A., Veeder, M., Kirkland, S., \& Lyon, D. (1990). Evidence for terror management theory II: The effects of mortality salience on reactions to those who threaten or bolster the cultural worldview. Journal of Personality and Social Psychology, 58, 308-318. http://dx.doi.org/10.1037//0022-3514.58.2.308

Greenberg, J., Solomon, S., \& Arndt, J. (2008). A basic but uniquely human motivation: Terror management. In J.Y. Shah \& W. L. Gardner (Eds.), Handbook of motivation science (pp. 114-134). New York: Guilford Press.

Han, S. P., \& Shavitt, S. (1994). Persuasion and culture: Advertising appeals in individualistic and collectivistic societies. Journal of Experimental Social Psychology, 30, 326-350. http://dx.doi.org/10.1006/jesp.1994.1016

Harris, R. J., \& Sanborn, F. W. (2014). A cognitive psychology of mass communication (6 ${ }^{\text {th }}$ ed.). New York: Routledge.

Heflick, N. A., \& Goldenberg, J. L. (2014). Dehumanization: A threat and solution to terror management. In P.G. Bain, J. Vaes, \& J-P. Leyens (Ed.), Humanness and dehumanization (pp. 111-126). New York: Psychology Press.

Hofer, M. (2013). Appreciation and enjoyment of meaningful entertainment: The role of mortality salience and search for meaning in life. Journal of Media Psychology, 25, 109-117. http://dx.doi.org/10.1027/1864-1105/a000089

Kashima, E. S., Halloran, M., Yuki, M., \& Kashima, Y. (2004). The effects of personal and collective mortality salience on individualism: Comparing Australians and Japanese with higher and lower self-esteem. Journal of Experimental Social Psychology, 40, 384-392. http://dx.doi.org/10.1016/j.jesp.2003.07.007

Knobloch-Westerwick, S., Gong, Y., Hagner, H., \& Kerbeykian, L. (2013). Tragedy viewers count their blessings: Feeling low on fiction leads to feeling high on life. Communication Research, 40, 747-766. http://dx.doi.org/10.1177/0093650212437758

Landau, M. J., Goldenberg, J. L., Greenberg, J., Gillath, O., Solomon, S., Cox, C., Martens, A., \& Pyszczynski, T. (2006). The siren's call: Terror management and the threat of men's sexual attraction to women. Journal of Personality and Social Psychology, 90, 129-146. http://dx.doi.org/10.1037/0022-3514.90.1.129

Landau, M. J., Solomon, S., Greenberg, J., Cohen, F., Pyszczynski, T., Arndt, J., Miller, C. H., Ogilvie, D. M., \& Cook, A. (2004). Deliver us from evil: The effects of mortality salience and reminders of $9 / 11$ on support for President George W. Bush. Personality and Social Psychology Bulletin, 30, 1136-1150. http://dx.doi.org/10.1177/0146167204267988

Lewis, R. J., Tamborini, R., \& Weber, R. (2014). Testing a dual-process model of media enjoyment and appreciation. Journal of Communication, 64, 397- 416. http://dx.doi.org/10.1111/jcom.12101

Loughnan, S., Haslam, N., Murnane, T., Vaes, J., Reynolds, C., \& Suitner, C. (2010). Objectification leads to depersonalization: The denial of mind and moral concern to objectified others. European Journal of Social Psychology, 40, 709-717. http://dx.doi.org/10.1002/ejsp.755

McGregor, H. A., Lieberman, J. D., Greenberg, J., Solomon, S., Arndt, J., Simon, L., \& Pyszczynski, T. (1998). Terror management and aggression: Evidence that mortality salience motivates aggression against worldview-threatening others. Journal of Personality and Social Psychology, 74, 590-605. http://dx.doi.org/10.1037/0022-3514.74.3.590

Miller, C. H., \& Landau, M. J. (2005). Communication and terrorism: A terror management theory perspective. Communication Research Reports, 22, 79-88. http://dx.doi.org/10.1080/0882409052000343543 
Miller, C. H., \& Landau, M. J. (2008). Communication and the causes and costs of terrorism: A terror management theory perspective. In H. D. O'Hair, R.L. Heath, K.J. Ayotte, \& G. R. Ledlow (Eds.), Terrorism: Communication and rhetorical perspectives (pp. 93-128). Cresskill, NJ: Hampton Press.

Mongeau, P. A. (2013). Fear appeals. In J.P. Dillard \& L. Shen (Eds.), The Sage handbook of persuasion: Developments in theory and practice ( $2^{\text {nd }}$ ed., pp. 184-199). Thousand Oaks, CA: Sage.

Moore, J., Thorson, E., \& Leshner, G. (2011). Terror management theory and anti-tobacco advertising: An experimental examination of influence of death-explicit anti-tobacco messages on young adults. Journal of Health \& Mass Communication, 3, 5-29.

Nabi, R. L., Finnerty, K., Domschke, T., \& Hull, S. (2006). Does misery love company? Exploring the therapeutic effects of TV viewing on regretted experiences. Journal of Communication, 56, 689-706. http://dx.doi.org/10.1111/j.1460-2466.2006.00315.x

Oliver, M. B. (2008). Tender affective states as predictors of entertainment preference. Journal of Communication, 58, 40-61. http://doi: 10.1111/jcom.2008.58.issue-1.

Oliver, M. B., \& Bartsch, A. (2010). Appreciation as audience response: Exploring entertainment gratifications beyond hedonism. Human Communication Research, 36, 53-81. http://dx.doi.org/10.1111/j.1468-2958.2009.01368.x

Oliver, M. B., \& Woolley, J. K. (2011).Tragic and poignant entertainment: The gratification of meaningfulness as emotional response. In K. Döveling, C. von Scheve, \& E.A. Konijn (Eds.), The Routledge handbook of emotions and mass media (pp. 134-147). New York: Routledge.

Proulx, T. (2013). Beyond mortality and the self: Meaning makes a comeback. In K.D. Markman, T. Proulx \& M.J. Lindberg (Eds.), The psychology of meaning (pp. 71-87). Washington, D.C.: American Psychological Association. http://dx.doi.org/10.1037/14040-004

Pyszczynski, T., Greenberg, J., \& Koole, S. L. (2004). Experimental existential psychology: Exploring the human confrontation with reality. In J. Greenberg, S.L. Koole, \& T. Pyszczynski (Eds.), Handbook of experimental existential psychology (pp. 3-9). New York: Guilford Press.

Pyszczynski, T., Greenberg, J., \& Solomon, S. (1999). A dual-process model of defense against conscious and unconscious death-related thoughts: An extension of terror management theory. Psychological Review, 106, 835-845. http://dx.doi.org/10.1037//0033-295X.106.4.835

Pyszczynski, T., Greenberg, J., Solomon, S., \& Maxfield, M. (2006). On the unique psychological import of the human awareness of mortality: Themes and variations. Psychological Inquiry, 17, 328-356. http://dx.doi.org/10.1080/10478400701369542

Rieger, D., Frischlich, L., Högden, F., Kauf, R., Schramm, K., \& Tappe, E. (2015). Appreciation in the face of death: Meaningful films buffer against death-related anxiety. Journal of Communication, 65, 351-372. http://dx.doi.org/10.1111/jcom.12152

Routledge, C., Arndt, J., \& Goldenberg, J. L. (2004). A time to tan: Proximal and distal effects of mortality salience on sun exposure intentions. Personality and Social Psychology Bulletin, 30, 1347-1358. http://dx.doi.org/10.1177/0146167204264056

Rudman, L.A., \& Mescher, K. (2012). Of animals and objects: Men's implicit dehumanization of women and likelihood of sexual aggression. Personality and Social Psychology Bulletin, 38, 734-746. http://dx.doi.org/10.1177/0146167212436401

Sartre, J. P. (1956). Being and nothingness: An essay on phenomenological ontology. (Trans. H.E. Barnes). New York: Philosophical Library.

Shavitt, S., Johnson, T. P., \& Zhang, J. (2011). Horizontal and vertical cultural differences in the content of advertising appeals. Journal of International Consumer Marketing, 23, 297-310. http://doi: 10.1080/08961530.2011.578064.

Shehryar, O., \& Hunt, D. M. (2005). A terror management perspective on the persuasiveness of fear appeals. Journal of Consumer Psychology, 15, 275-287. http://doi: 10.1016/S1057-7408 (05)70118-2.

Slater, M. D., Johnson, B. K., Cohen, J., Comello, M. L. G., \& Ewoldsen, D. R. (2014). Temporarily expanding the boundaries of the self: Motivations for entering the story world and implications for narrative effects. Journal of Communication, 64, 439-455. http://doi:10.1111/jcom.12100.c

Solomon, S., Greenberg, J., \& Pyszczynski, T. (2004). The cultural animal: Twenty years of terror management theory and research. In J. Greenberg, S.L. Koole, \& T. Pyszczynski (Eds.), Handbook of experimental existential 
psychology (pp. 13-34). New York: Guilford Press.

Stroud, N. J. (2011). Niche news: The politics of news choice. New York: Oxford University Press. http://dx.doi.org/10.1093/acprof:oso/9780199755509.001.0001

Swing, E. L., \& Anderson, C. A. (2010). Media violence and the development of aggressive behavior. In M. DeLisi \& K.M. Beaver (Eds.), Criminological theory: A life-course approach (pp. 87-108). Sudbury, MA: Jones and Bartlett.

Tamborini, R. (2011). Moral intuition and media entertainment. Journal of Media Psychology, 23, 39-45. http://dx.doi.org/10.1037/0022-3514.76.1.35

Taubman Ben-Ari, O., Florian, V., \& Mikulincer, M. (1999). The impact of mortality salience on reckless driving: A test of terror management mechanisms. Journal of Personality and Social Psychology, 76, 35-45.

Vail, K. E. III, Juhl, J., Arndt, J., Vess, M., Routledge, C., \& Rutjens, B. T. (2012). When death is good for life: Considering the positive trajectories of terror management. Personality and Social Psychology Review, 16, 303-329. http://dx.doi.org/10.1177/1088868312440046

Vorderer, P., Klimmt, C., \& Ritterfeld, U. (2004). Enjoyment: At the heart of media entertainment. Communication Theory, 14, 388-408. http://dx.doi.org/10.1111/j.1468-2885.2004.tb00321.x

Waterman, A. S. (1993). Two conceptions of happiness: Contrasts of personal expressiveness (eudaimonia) and hedonic enjoyment. Journal of Personality and Social Psychology, 64, 678-691. http://dx.doi.org/10.1037//0022-3514.64.4.678

Witte, K. (1992). Putting the fear back into fear appeals: The extended parallel process model. Communication Monographs, 59, 329-349. http://dx.doi.org/10.1080/03637759209376276

Young, K. (2015, January 26). Oblivion. The New Yorker, 68.

Zanna, M. P., \& Fazio, R. H. (1982). The attitude-behavior relation: Moving toward a third generation of research. In M. P. Zanna, E. T. Higgins, \& C. P. Herman (Eds.) Consistency in social behavior: The Ontario symposium (Vol. 2, pp. 283-301). Hillsdale, NJ: Lawrence Erlbaum Associates.

Zillmann, D. (1988). Mood management: Using entertainment to full advantage. In L. Donohew, H.E. Sypher, \& E.T. Higgins (Eds.), Communication, social cognition, and affect (pp. 147-171). Hillsdale, NJ: Lawrence Erlbaum Associates.

Zillmann, D., \& Bryant, J. (1982). Pornography and sexual callousness, and the trivialization of rape. Journal of Communication, 32, 10-21. http://dx.doi.org/10.1111/j.1460-2466.1982.tb02514.x

\section{(c) EY}

This work is licensed under a Creative Commons Attribution 3.0 License. 